\title{
THE IMPORTANCE OF LEAN MANUFACTURING AND SIX SIGMA CONCEPT FOR QUALITY MANAGEMENT OF SUPPLY CHAIN BUSINESS PROCESSES
}

\author{
UDC 658.5.012.2
}

\author{
Jovana Stojanović*, Goran Milovanović \\ University of Niš, Faculty of Economics, Republic of Serbia
}

\begin{abstract}
The aim of this paper is to evaluate the importance of lean and six sigma concepts and techniques on the basis of systematic knowledge gathered from relevant scientific sources, both for discovering supply chain processes where potential waste can occur and for improving the quality of those processes. The paper will first outline the key features and effects of applying lean and six sigma concepts in manufacturing and supply chains. The focus is on the frameworks and potentials of implementing the lean concept in the Republic of Serbia. Then, the possibilities of integrating these concepts into the lean six sigma concept are presented and its role in eliminating defects in business processes. The penultimate part of the paper outlines the key features of lean supply chain while the final part contains the mathematical frameworks for designing six sigma supply chains.
\end{abstract}

Key words: lean manufacturing, six sigma, lean supply chain, business process, delivery precision

JEL Classification: L15, M11, M16

\section{INTRODUCTION}

Fast and unpredictable changes in the business environment require companies to constantly struggle to gain and maintain a competitive edge. In order to gain and maintain their competitive advantage in such an environment, companies (suppliers, manufacturers, carriers and traders) tend to minimize inventory, shorten the order process, manufacturing and delivery time to end customers and reduce overall costs.

Received December 18, 2019 / Revised April 11, 2020 / Accepted April 29, 2020

Corresponding author: Jovana Stojanović

* PhD Student at University of Niš, Faculty of Economics

University of Niš, Faculty of Economics, Trg kralja Aleksandra 11, 18000 Niš, Serbia

E-mail: jovana.stojanovic992@gmail.com 
Companies are increasingly seeking to improve business process performance by implementing lean and six sigma concepts. Their integration creates the lean six sigma concept (LSS), which is much more than a methodology for efficient project realization. By implementing the LSS concept, companies reduce or eliminate the weaknesses of both concepts - lean cannot bring a particular business process under statistical control while six sigma cannot significantly increase the speed of a business process or reduce capital investment.

The following parts of the paper first point out that, by implementing lean concept, companies can minimize or eliminate various types of waste such as unnecessary flows of materials and people, unnecessary waste of time and excess inventory. We pay special attention to the effects of applying lean principles and techniques in manufacturing. What follows is a brief outline of the lean concept business frameworks in the Republic of Serbia and then the role of the six sigma concept in identifying and eliminating errors in supply chain business processes. The fourth part of this paper deals with the specifics of integrating these concepts and using them to improve the quality of companies' production and transactional processes. The fifth part of the paper briefly discusses the characteristics of lean supply chains, while the final part of the paper is reserved for designing six sigma supply chains based on linear programming.

\section{LEAN BUSINESS CONCEPT AND LEAN MANUFACTURING}

Lean business concept is a management philosophy aimed at eliminating all kinds of business process defects in the company. With the help of various instruments and techniques applied, this concept can help ensure continuity of production, eliminate waste, increase the level of quality, but also optimize human resources, tools and productivity. However, for the lean concept to have the expected effects, all company employees must understand the essence of the concept and focus on its proper implementation. Employees should first be trained to recognize waste (defects, errors, waiting, excess inventory, etc.) that reduce the value of output, and then use adequate lean tools to eliminate waste.

The implementation of the lean concept is not only an issue for individuals but for the whole company. However, it is up to the company management to evaluate whether and under what conditions it will be implemented.

Looking at the development of the lean business concept, it can be noticed that in the initial stages of development this business model was related exclusively to the production process. The lean production philosophy comes from the Toyota Production System (TPS) described in the book "The Machine That Changed the World". At the operational level, with the help of certain lean techniques and tools, the aim was to eliminate waste, deliver the required value to customers, and achieve pre-set performance. The goal was to improve efficiency and reduce costs in the production process. With the evolution of the lean business concept, towards the end of the previous century, the management center was shifted from operational to strategic level. At this level, the goal was to understand the value that needed to be provided to customers in terms of quality, price, functionality and shorter delivery time (Novićević Čečević \& Antić, 2016, p. 274).

Although initially the lean concept was applied only in production, later it began to be applied in health, state and local government, as well as in education. Many countries and cities around the world are implementing the lean concept today. Since 2012, China has 
been implementing lean methods and techniques in healthcare, while Canada has long had a minister for lean. Despite the fact that almost all foreign companies operating in the Republic of Serbia work under "lean" management, it is still an enigma in the Republic of Serbia.

After developing production with lean elements, lean principles and techniques give full effect if all company employees are committed to their application. That is how a lean company comes into being, which is much more than lean production. Becoming aware of business performance improvement, company managers then strive to apply lean principles and techniques outside the company, thus creating a lean supply chain.

Lean manufacturing is a comprehensive business system that strives to accelerate all processes. Lean manufacturing involves applying the following key lean concept principles:

- Recognize waste - recognize all non-value-added processes,

- Standardize processes - define precise and detailed procedures that reduce variability,

- Create a "value stream" - eliminate non-value-added activities, reduce defects, interruptions, eliminate waste, etc.,

- Perform only the necessary processes and only when necessary,

- Detect errors in their initial phase, and

- Strive for perfection by constantly eliminating waste (Moeller, 2009, p. 313).

Lean manufacturing includes the concept of "nine zeros", which implies the complete elimination of: 1) partner dissatisfaction, 2) mismatch, 3) bureaucracy, 4) dissatisfied stakeholders, 5) delayed information, 6) waste, 7) non-value-added work , 8) errors, and 9) missed chances (Charron et al., 2015, pp. 107-108). Lean production tends to low-level work-in-progress flow, without stopping the production process and without storage (Cooper \& Slagmulder, 1999, pp. 23-33). Lean production has the character of a revolutionary process. It strives for continuous improvement of the process and work area to ensure that work is done effectively.

\section{THE LEAN CONCEPT IN THE REPUBLIC OF SERBIA WITH AN OVERVIEW OF THE HEALTHCARE SECTOR}

The awareness of Serbian managers of the importance of lean concept, both in companies and in state administration and local self-governments, is growing, but it has not yet reached the level of developed countries. People leading companies, institutions and self-governments still do not understand the business mission of the lean concept. One of the reasons for this situation in the Republic of Serbia is that managers are not familiar enough with assumptions and principles underlying the concept. In addition, the volume of work and fear of the unknown prevent managers from embarking on promoting lean principles and trying to reduce waste and improve business process performance without major investment. Managers are de facto not aware enough that implementing lean techniques and tools leads to the shortest possible lead time in service delivery while eliminating waste. A key consequence of this is the lack of economic benefits (increasing productivity, eliminating duplicate operations, increasing profits) generated by lean techniques and tools.

Fortunately, those responsible for a growing number of companies, health care, public administration and local governments in the Republic of Serbia realize that to implement the lean concept in practice on a broader scale, it is necessary to initiate lean transformation 
and create lean culture, based on the principle of "do more with less". Although with unequal speed and success, the scope of this concept is expanding.

The lean concept is based on a continuous drive to meet customer needs while reducing unnecessary spending and wastage. In the spirit of continuous improvement of the process, this concept is oriented towards finding errors and their causes, which creates a positive effect on performance, in the form of higher quality, lower costs, as well as shorter production (delivery) time of the product. The lean concept not only contributes to greater process efficiency through optimization of internal processes, but also creates a positive effect on business efficiency by advocating the implementation of the necessary activities only, when needed, in a specific amount, with reduced resource consumption (Todorović, 2013, p. 10). Improving effectiveness (doing the right thing) and efficiency (doing it the right way) increases customer satisfaction and improves employee self-esteem.

Through lean transformation, business processes in companies, government, local governments and healthcare become simpler and more efficient. With this transformation, the logic of "we have always done it that way" gives way to the logic of "we can do more with less".

With a higher level of employee training on lean logic and strategy, companies as well as institutions and governments can significantly improve the performance of their business processes.

Successful examples of lean transformation in the world, especially in entrepreneurship, the public sector and health, are not a panacea, but models of process improvement that can be of benefit to managers in the Republic of Serbia. The lean concept is not only reserved for production, but for every job and process. Whether the Republic of Serbia will become a world-class community - a place where people want to live and work and companies to invest and locate their resources, without defects and at a reasonable price - depends largely on whether lean business transformation will become possible, an environmentally sustainable and long-term profitable endeavour.

The increasing importance of the service sector over the last few decades has brought the lean concept to the service sector as well. Managers of various institutions, organizations and companies are becoming increasingly aware that the lean concept is strategically oriented to achieve the shortest lead time of service delivery while eliminating different types of waste.

Healthcare institutions around the world have recognized the importance of applying the lean concept in the process of providing healthcare services and have begun to apply some of its tools and techniques. The lean concept is also being applied in healthcare institutions in the Republic of Serbia. According to the research results (Stoiljković, 2013), most foreign companies operating in the Republic of Serbia apply some of the six sigma tools and techniques, i.e. the lean concept. However, despite the seminars held on this topic, the interest of managers of domestic companies has almost never been at the level of interest of managers of foreign companies operating in the Republic of Serbia.

The Clinical Center in Niš has implemented two lean projects. The first project used lean tools, such as $5 \mathrm{~S}$ and standardization of work, to reduce wastage in business processes (errors, redundant work, waiting, underutilized human potential, transportation, supplies, unnecessary movement and unnecessary processing) identified by teams in charge of the process improvement. During the course of the project, team members went through various types of lean techniques training, including training on the JIT lean concept technique. In the implementation of the second lean project, the aim was to achieve goals such as shortening 
the process time, increasing the quality of health services, reducing errors, freeing up space and reducing inventory level.

Results of implemented lean projects indicate that losses and overload in the business process were successfully recognized in the health system of the Clinical Center in Niš. With the help of some lean tools, it took months to reduce them. Since correcting and eliminating defects at the time when they have already occurred can be a costly, timeconsuming and complicated process, attention should be paid to detecting errors in their initial stages of development, as an essential principle of the lean concept.

The project managers were able to adequately use the standardization of work, as one of the lean tools, which was not easy at all. The application of this tool in the case of provision of healthcare services could be a challenge for managers, given the heterogeneity of certain patient requirements. However, the staff of the Clinical Center in Niš were persistent, using this lean tool mainly for recurring activities.

We believe that the implementation of the mentioned projects depended significantly on the experience of the experts, but also on the positive attitude of the employees towards the changes, as well as on their willingness to accept such changes in order to increase the quality of healthcare services. Among the many factors on which the success of the lean concept depends, great importance is attached to the impact that employees have, as the carriers of the current or future process.

In addition, the developed information technology has made it possible to apply lean tools in different areas of healthcare at the Clinical Center. With digitalization, some processes have become more efficient, with the greater ability to track them. Such business conditions have enabled better data analysis as well as more accurate and secure diagnostics.

So, in order to improve business, organizations in the Republic of Serbia should consider modifying the business culture and finding ways to eliminate unnecessary spending and non-value-added activities. Unfortunately, managers and employees are still having a difficult and slow time changing their mindset. Therefore, any change requires educated managers and employees who understand that their new business culture will enable them to make more profit. Employees must have leaders who themselves understand the need for change and show an interest in the new business concept. But, mostly because of established work habits, employees can resist the very mention of change.

In order to improve overall business performance, domestic companies should apply the lean concept on a larger scale. Due to the growing economic internationalization of the Republic of Serbia and the inflow of foreign capital from parent foreign companies, one can expect positive changes in the field of applying the lean concept.

\section{Six Sigma Concept And its Relevance to Business Process Performance}

The six sigma revolution started in Motorola in the 1980s. As a concept of process-oriented quality management, six sigma has attracted the attention of scientists and practitioners, as it is based on a comprehensive analysis of a network of business processes aimed at creating and delivering value to consumers.

Six sigma is a business management strategy used by companies to help improve process quality by identifying and eliminating the causes of deficiencies, while striving to keep variations in the manufacturing process to a minimum (Wedgwood, 2006). According to Mustapha \& Muda (2012, p. 693), by implementing the six sigma concept, an organization can 
significantly improve the execution of its business process by monitoring day-to-day business activities so that losses and resources are reduced while increasing the level of customer satisfaction.

Theorists suggest that implementing this concept requires the use of statistics to determine average values of process performance, that is, average differences in performance and quality of results (O'Rourke, 2005, p. 14). Six sigma is based on the assumption that process performance data can be represented by a normal distribution curve. Based on the established deviations of the actual process indicators from the normal distribution curve, it is possible to evaluate the quality of the process.

Today, $1.5 \sigma$ is considered to be the "standard" for the worst case of shifting the mean of the process. The $1.5 \sigma$ is the result of the natural process instability. If the shift of the process mean around the expected value is $1.5 \sigma$, the number of values that go beyond the limits increases to 3.4 per million possibilities (3.4 DPMO). The range between the Upper Specification Limit (USL) and the Lower Specification Limit (LSL) represents the specification range (Figure 1).

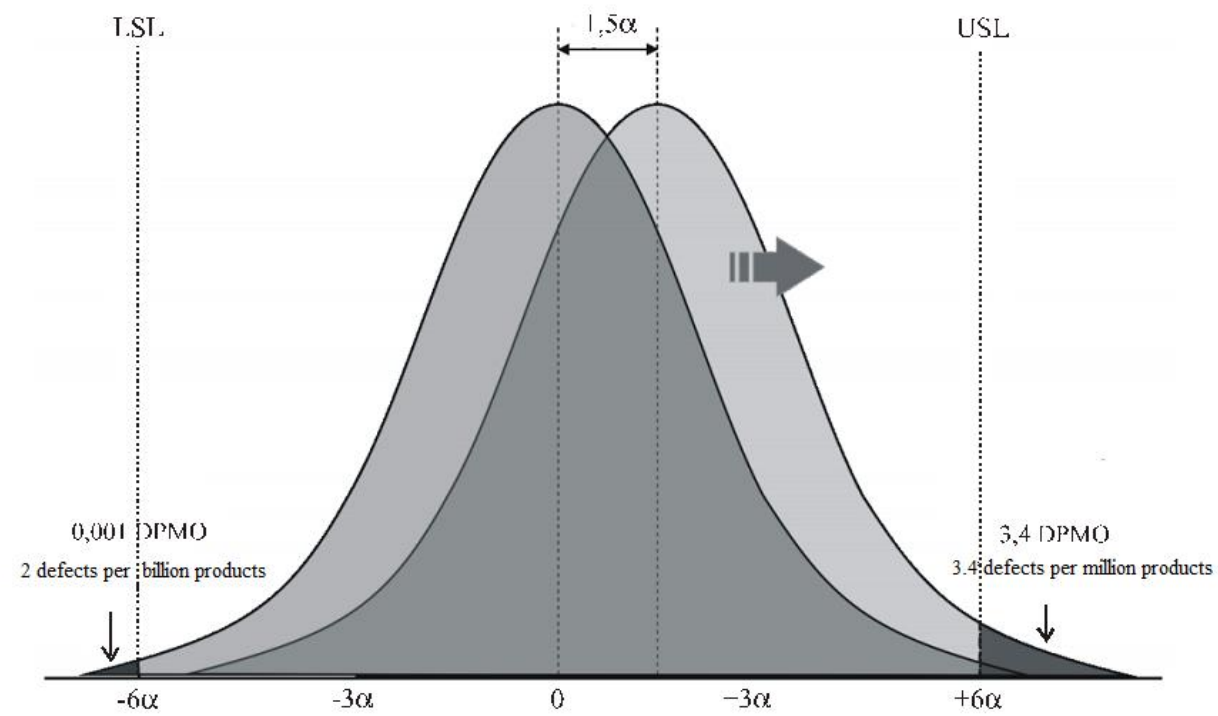

Fig. 1 Process mean shift

Source: ŠEST SIGMA (http://www.tfzr.uns.ac.rs/Content/files/0/KONCEPT_SIX_SIGMA.pdf)

Figure 1 shows that if the statistical set is subject to normal distribution, the area under the curve bounded by $\pm 6 \sigma$ comprises $99.9999998 \%$ of that set. This means that two values per billion values go beyond the aforementioned limits.

Organizations should implement the six sigma concept according to DMAIC (Define, Measure, Analyze, Improve, Control) methodology and quantified financial goals. The implementation of the six sigma concept according to the DMAIC methodology takes place through five stages. The first stage is defining the problem to be solved. The aim of this phase is to bring the business process performance to a predefined level, i.e. within the allowed 
deviation level. In the second phase, appropriate measuring tools are used, with the aim of determining the limits of the deviation. During this phase, a process map is created and relevant data collected. The process maps are first produced at a high level and then continually refined as quantitative data is constantly collected. At this stage, graphical analyses of deviations, such as time series graphs, Pareto diagrams, etc., are made, displaying data in chronological order and process change over time. The preceding procedure sets the stage for the third stage, i.e. development of analytical tools to identify the cause of deviations. In the fourth phase, deviations are eliminated with the help of key factors identified in the analysis. In the last phase, the results from the previous stages are controlled and monitored in order to improve and prevent the recurrence of the errors observed (O'Rourke, 2005, pp. 1516). The DMAIC relies on a PDCA cycle, with the basic difference that it refers to the project life cycle (exclusive project orientation), whereas the PDCA, as a tool, is used specifically in the management phase.

The implementation of the six sigma concept contributes to improving the performance of the enterprise, focusing on process changes through constant work to reduce errors and defects. As an instrument that transforms the way business is done and places emphasis on control and quality, six sigma enables businesses to gain significant competitive advantage. "Some analyses indicate that the application of this concept allows for business results to be improved by up to $20 \%$, quality improvement by $12-18 \%$ and cost reduction by 10 30\%" (Todorović, 2013, p. 70).

Authors examining the relationship between the six sigma concept and its effects on performance generally agree that six sigma has positive effects on the organization's performance (Ertürk et al., 2016). The results of the empirical research of these authors show that companies using six sigma methodology achieve better operational, but also financial performance that exceeds funds invested in the new business concept. Thanks to the DMAIC methodology, companies have been able to achieve greater efficiency and productivity, reduce operating costs, which has ultimately led to greater customer satisfaction.

According to Hammer (2002), six sigma uses a methodology based on solving a specific problem identified in the company. In this context, it is necessary to engage employees and professionals with adequate knowledge and skills to apply the techniques and tools. One of the significances of this concept is precisely the orientation towards organizational and personnel structure, which clearly defines knowledge and skills that are necessary to overcome problems and improve the process (Todorović, 2013, p. 71).

Companies where the six sigma concept had a positive impact on business performance had a well-defined process as well as adequately applied information technology (Rajamanoharan $\&$ Collier, 2006). The analyzes of these authors also show that companies that had an adequate performance measurement system were able to eliminate defects, that is, to ensure the quality of the process.

On the other hand, there are companies that have failed to take advantage of the positive effects that six sigma provides. Some scientists believe that managers have not adequately understood the principles and risks of this concept, stating that this concept simply repackages the traditional quality management system (Dahlgaard \& Dahlgaard-Park, 2006).

However, the emerging trend aimed at advancement is the integration of lean and six sigma concepts, which opens up new business improvement opportunities. 


\section{INTEGRATION OF LEAN AND SiX SigMA CONCEPTS - A PREREQUisite FOR BUSINESS PROCESS IMPROVEMENT}

Ways to improve business processes within the company have changed throughout history. Formerly, business process improvements were made solely with the help of machines that accelerated production, while today this process may involve the use of different statistical methods to analyze companies, business processes and individuals. In addition to reducing costs and increasing quality, successful business improvement also requires a change in company culture, which should motivate employees to constantly work to improve business processes and business policies. Such change requires the support of structural methods and continuous improvement programs (O'Rourke, 2005, p. 1).

LSS is primarily a company philosophy that focuses on constantly improving its performance through systematic waste elimination as well as reducing process variation. LSS combines lean manufacturing/lean company principles and six sigma to eliminate eight types of waste (Muda). The six sigma concept is more about the process quality, and the lean concept is about the speed of its implementation. The integration of these concepts into the LSS concept provides the basis for improving production and transaction processes in the company, without considering that they are based on different methodologies and principles for achieving improvement.

The implementation of the LSS concept involves the planned and phased implementation of effective tools and many other business concepts. The LSS concept provides a framework for changing the overall organizational culture (Knapp, 2015, pp. 855-863). However, there is no model for implementing the LSS concept to suit the needs and capabilities of each company.

By combining lean and six sigma concepts, a company can increase revenues, reduce costs, improve internal and external collaboration and, therefore, the process quality (Sunder, 2016, pp. 132-150). Many companies and organizations have embraced lean, six sigma, and LSS concepts as strategies for finding a balance between quality, cost and delivery time. The question of "which of these strategies to use first to improve the quality of the business process" is always present. The answer to this question depends on the nature of the problem and the goal pursued (Antony, 2014, pp. 257-264).

\section{LEAN SUPPLY CHAIN}

In order to fully implement lean transformation and achieve a satisfactory competitive market position, managers should first apply lean principles and techniques in production and in all other company parts and then beyond. To achieve this, managers need to redefine company strategies and identify key processes performed. When lean principles and techniques are applied outside the company, a lean supply chain is formed, with suppliers, manufacturers, distributors, organizations that store goods and end customers. Lean supply chain strives to optimize the services provided while minimizing costs. It presupposes effective communication, transfer of information, synchronization of flows, elimination of waste and establishment of a long-term cooperation between its participants (Novićević Čečević, 2016, p. 74).

Key features of the lean supply chain are: "member integration; effective communication and exchange of information; effective demand management; focusing on the end customer; continuous improvements; low inventory and small number of suppliers; and continuous flow and long-term contracts between members" (Ugochukwu et al., 2012, p. 92). Significant 
improvement in the management of such a supply chain is most evident in manufacturing. The production process can be improved to reduce waste, resources, and non-value-added activities, while maintaining operational performance at the same level. If managers do not implement adequate strategies to reduce these deficiencies, the opportunities for creating an efficient supply chain may drop (Milovanović et al., 2017, pp. 31-40).

Lean supply chain, especially the one that applies to multinational companies, requires lean logistics. Lean logistics is associated with certain challenges that multinational companies face. The greater the number of such companies in the supply chain, the greater the likelihood of disturbing flow synchronization. For example, international shipments require the inclusion of more different companies in the supply chain (e.g. suppliers, port organizations, freight forwarders, customs brokers, railways, air and ocean freight companies) than domestic shipments. Implementing lean logistics in such a large supply chain is not an easy task. This means that some of the companies involved work together and face each single delivery at the same time, resulting in waste and non-value-added activities.

\section{Implementation of the Six Sigma Concept in the Supply Chain}

The implementation of the six sigma concept in the supply chain takes four phases in order to test, analyze, improve and standardize improved business processes (Kilibarda, 2005). The first phase defines the entire supply chain from the supplier to the end customer, with particular reference to identifying the processes and activities that take place there. The next phase involves measuring and analyzing those processes. De facto, for each process, relative performance, defects, and opportunities for error are identified. The third phase is to identify activities that influence process improvement, using appropriate methodologies to identify and, if possible, eliminate those non-value-added activities. The final phase standardizes the realized quality improvements by individual processes (Maslarić \& Cakić, 2006, p. 189). Motorola has won the Malcolm Baldrige National Quality Award based on the results of the six sigma concept implementation.

In modern business, just-in-time delivery of inventory within the supply chain is considered an important indicator of the quality of logistics services. A supply chain cannot be competitive on the market unless all its business processes are aligned. To achieve this, company managers should strive to minimize process variability within the supply chain (Garg et al., 2004).

Maslarić and Cakić outline one of the quality measurement concepts relating to respecting the delivery time of inventory to a particular participant in the supply chain. Given that the supply chain consists of multiple processes, the basic idea Maslaric and Cakić advocate is to find a way to supply inventory in a timely manner between participants at different stages of the supply chain (Maslarić \& Cakić, 2006, p. 190).

In order to deliver inventory quickly and accurately to their customers in the supply chain, there is a need for a high degree of synchronization across business processes - from the supply of raw materials to the delivery of the finished product to the end customer. With the increase in the volume of resources and the number of operations and organizations in the supply chain, variability of supplies among its members increases. Managers need to improve the delivery of inventory within the supply chain and thus its competitiveness and profitability.

Garg et al. introduce a new concept of quality performance measurement - the "accuracy of logistics service delivery time", called six sigma supply chains. Six sigma 
describes and quantifies supply chains in terms of fast and accurate delivery and develops a new approach to design such networks. Their basic idea is to draw an analogy for the functioning of supply chains with complex assemblies (mechanical, electro-mechanical, etc.), where statistical tolerance has become widely used (Garg et al., 2004). De facto, these authors compare the functioning of the supply chain with complex assemblies, where statistical tolerance within mechanical tolerance has been widely used. The complex supply chain network resembles a complex electromechanical assembly. Each individual business process in a given supply chain is analogous to a single sub-assembly within a complete assembly. Minimizing obsolete inventory within the supply chain can be seen as minimizing defects in electromechanical assemblies (Garg et al., 2004).

Garg et al. have chosen to explore three current areas, namely: 1) reducing the variability of supply time between supply chain participants, 2) statistical tolerance, and 3) the six sigma concept (Garg et al., 2004).

To reduce the variability of supply chain business processes, it is first necessary to determine the $\mathrm{Cp}$ process capability indicators (precision index or process potential index), Cpk (capability index) and Cpm (machine potential capability) and define the relationships between them. On this basis, a new measure of delivery time performance is defined, which is called respect for delivery deadlines (precision), i.e. number of wrong deliveries (WD) in addition to the existing measure - probability of delivery accuracy (DA). Lastly, WD is included in the six sigma concept used in designing quality across supply chains. The six sigma supply chain is the supply chain in which the number of occurrences of wrong deliveries (WD) is not more than 3.4 per million possible cases (Maslarić \& Cakić, 2006, p. 190).

Proper supply chain design is implemented to deliver supplies between each of its participants at a time interval that should largely coincide with the required delivery time of the inventory. Garg et al. respect the fact that the supply chain encompasses a large number of business processes between its individual participants. The number of business processes is denoted by $n$. Each of these processes takes place over a period of time - from the moment the participant orders a particular type of stock to the moment of delivery. With $\mathbf{x}_{\mathbf{i}}$ they indicate the delivery time of inventory for a given process $\mathbf{i}$, where each $\mathbf{x} \mathbf{i}$ represents a variable with mean $\mu_{\mathbf{i}}$ and standard deviation $\sigma_{\mathbf{i}}$ (Garg et al. 2004, p. 45). Given the above, the total delivery time of inventory between participants within the supply chain (Y) can be represented by the following function:

$$
Y=f\left(x_{1}, x_{2}, \ldots, x_{n}\right)
$$

Assuming that the cost of delivering inventory between participants in the supply chain is a function of the mean $\left(\boldsymbol{\mu}_{\mathbf{i}}\right)$ and standard deviation $\left(\boldsymbol{\sigma}_{\mathbf{i}}\right)$, the cost of delivering inventory between participants in the entire supply chain $(\mathbf{Z})$ can be represented by the following function:

$$
Z=g\left(\mu_{1}, \sigma_{l}, \ldots, \mu_{n}, \sigma_{n}\right)
$$

Each participant in the supply chain, as the ordering party of a particular type of inventory at a particular stage of the process, defines the lower and upper limit of the time interval within which they are prepared to wait for the delivery of the required inventory.

With this in mind, supply chain design can be seen as a linear programming model that requires the minimum value of the following objective function to be determined:

$$
\min Z=g\left(\mu_{l}, \sigma_{l}, \ldots, \mu_{n}, \sigma_{n}\right)
$$

subject to the following limitations: 
DP for total delivery time $\geq \mathbf{C} * \mathbf{p m}$

DA for total delivery time $\geq \mathbf{6} \boldsymbol{\sigma}$

$$
\begin{aligned}
& \mu_{1}>0 \\
& \sigma_{1}>0
\end{aligned}
$$

C*pm requires a lower limit for a defined DP performance measure (Maslarić \& Cakić, 2006, p. 191). The solution of the set linear programming model gives values for the parameters $\mathbf{x}_{\mathbf{i}}$ of all business processes in the supply chain, which satisfy all the necessary limitations and conditions, i.e. ensure the quality of delivery time at the level of six sigma. This means that the goal of supply chain companies is to complete all processes so that all parameters of each process have the lowest precision index (potential) $\mathrm{Cp}=2$. In this case, less than 3.4 defects per million possible occur in the supply chain processes.

\section{CONCLUSION}

With the help of an adequate logistical strategy, and in order to survive in the market, it is possible to fulfill all the increasingly specific consumer needs related to the delivery of the right product, at the right time and at the right price. When the company understands the demands of the market and has the access thereto, the logistics strategy created can be tailored to the needs of the supply chain as well as to the needs of end customers. Companies can improve the quality of their business processes by eliminating waste and non-value-added activities by adequately managing their supply chain, with a thorough analysis of each part of that chain.

Regardless of their independent evaluation, today lean and six sigma represent logistics disciplines and tools that can be used to identify waste, in terms of time, cost and supplies, as well as different types of process inefficiencies.

In the spirit of continuous improvement in order to minimize various forms of waste, the lean concept is focused on simplicity, speed, flexibility, transparency of business processes and their integration into a continuous flow. Since the supply chain includes a great number of business processes among its individual participants, the lean concept is one of the important factors for their integration and synchronization. Due to the relentless pursuit of continuous improvement, the lean is focused on identifying quality problems in the order fulfillment process through the supply chain, and the application thereof can indicate the place in the supply chain where quality defects occur.

Developed by expanding the lean concept with the use of advanced statistical tools, the six sigma concept has found its place not only within companies but also in their supply chains. The presented supply chain design model clearly shows that in order to achieve a satisfactory level of quality (compliance with deadlines) of delivery, it is necessary to bring the processes and activities of the supply chain as close as possible to the six sigma level. In today's business environment, achieving high quality can be realized through the use of new supply chain technology, thereby reducing variability, having greater business process synchronization, and therefore better performance within the supply chain.

With a sufficient level of interconnection and compatibility, by integrating the previous two concepts, the lean six sigma concept was created. By implementing this concept, companies and supply chains can improve business processes and maximize value for 
consumers and owners. Given the exceptional application possibility, as well as through numerous synergy effects, lean and six sigma integration, it is possible to achieve satisfactory results when it comes to minimizing unnecessary wastage, and to achieve high quality in delivering value to participants within the supply chain.

With respect to the degree of depletion of the lean concept potential, the Republic of Serbia is still inferior to the developed countries. However, managers of a growing number of companies are successfully promoting lean principles and demonstrating how it is possible, without major investment, to apply lean techniques and tools to reduce waste and increase business process performance.

\section{REFERENCES}

Antony, J. (2014). Readiness factors for the Lean Six Sigma journey in the higher education Sector. International Journal of Productivity and Performance Management, (63)2, 257-264.

Charron, R., Harrington, J., Voehl, F., \& Wiggin, H. (2015). The Lean Management Systems Handbook. London: Taylor \& Francis Group LLC.

Cooper, R., \& Slagmulder, R. (1999). Develop profitable new products with Target costing. Sloan Management Review, (40)4, 23-33.

Dahlgaard, J. J., \& Dahlgaard-Park, S. M. (2006). Lean production, six sigma quality, TQM and company culture. The TQM Magazine, 18(3), 263-281.

Ertürk, M., Tuerdi, M., \& Wujiabudula, A. (2016). The Effects of Six Sigma Approach on Business Performance: A Study of White Goods (home appliances) Sector in Turkey. Procedia - Social and Behavioral Sciences, $229,444-452$.

Garg, D., Narahari, Y., \& Viswanadham, N. (2004). Design of Six Sigma Supply Chains. IEEE Transactions on Automation Science and Engineering, 1(1), 38-57.

Hammer, M. (2002). Process Management and the Future of Six Sigma. MIT Sloan Management Review, 43(2), 26-32.

Kilibarda, J. M. (2005). Modeliranje performansi kvaliteta logističke usluge [Quality Performance Modeling Logistical Service]. Ph.D. Thesis. Beograd: Saobraćajni fakultet.

Knapp, S. (2015). Lean Six Sigma implementation and organizational culture. International Journal of Health Care Quality Assurance, 28(8), 855-863.

Maslarić, M., \& Cakić, Đ. (2006). Koncept šest sigma u lancima snabdevanja [Concept Six Sigma in Supply Chains]. Festival kvaliteta 2006. „33. Nacionalna konferencija o kvalitetu”, 10-12. maj. Kragujevac: Asocijacija za kvalitet i standardizaciju Srbije.

Milovanović, G., Milovanović, S., \& Radisavljević, G. (2017). Globalization - the key challenge of modern supply chains. Ekonomika, (63)1, 31-40.

Moeller, B. (2009). Brink's Modern Internal Auditing - A Common Body of Knowledge. $7^{\text {th }}$ Edition. New Jersey: John Wiley \& Sons, Inc.

Mustapha, M., \& Muda, M. (2012). Lean Six Sigma and Operational Audit as a New Paradigm for Improvement. Proceedings Business in Asia: Global Challenges and Sustainability at the International Conference on Business and Management (IBSM 2012), 6-7 September, Phuket, Thailand, 690-699.

Novićević Čečević, B. (2016). Upravljačko - računovodstvena podrška menadžmentu preduzeća u lean poslovnom okruženju [Managerial Accounting Support to the Enterprise Managmenet in a Lean Business Environment]. Ph.D. Thesis. Niš: Ekonomski fakultet.

Novićević Čečević, B., \& Antić, Lj. (2016). Value stream performance measurement and the lean business concept. Facta Universitatis, Series: Economics and Organization, (13)3, 273-286.

O'Rourke, P. (2005). A multiple-case comparison of Lean Six Sigma deployment and implementation strategies. Master Thesis. Wright-Patterson Air Force Base, Ohio: AIR Force Institute of Technology.

Rajamanoharan, I. D., \& Collier, P. A. (2006). Six Sigma implementation, organizational change and the impact on performance measurement systems. International Journal of Six Sigma and Competitive Advantage, 2(1), 48-68.

Stoiljković, V. (2013). Lean u zdravstvu [Lean in Health]. Niš: Despot book.

Sunder, V. (2016). Lean six sigma project management - a stakeholder management Perspective. The TQM Journal, (28)1, 132-150.

ŠEST.SIGMA. Retrieved from http://www.tfzr.uns.ac.rs/Content/files/0/KONCEPT_SIX_SIGMA.pdf. Accessed on: 16 October 2019 
Todorović, M. (2013). Obračun troškova po aktivnostima baziran na vremenu - instrument integrisanog upravljanja lean poslovnim procesima [Time-Driven Activity-Based Costing - an instrument of integrated lean business process management]. Ph.D. Thesis. Kragujevac: Ekonomski fakultet.

Ugochukwu, P., Engstrom, J., \& Langstrand, J. (2012). Lean in the supply chain: a literature review. Management and Production Engineering Review, (3)4, 87-96.

Wedgwood, I. (2006). Lean Sigma: A Practitioner's Guide. New Jersey: Prentice Hall.

\section{ZNAČAJ LEAN PROIZVODNJE I SIX SIGMA KONCEPTA ZA UPRAVLJANJE KVALITETOM POSLOVNIH PROCESA LANCA SNABDEVANJA}

Cilj rada je da se na bazi sistematizovanih saznanja, prikupljenih iz relevantnih naučnih izvora, oceni značaj lean i six sigma koncepta i tehnika, kako za otkrivanje procesa lanca snabdevanja $u$ kojima se mogu javiti potencijalni gubici, tako i za unapređenje kvaliteta tih procesa. U radu će najpre biti predstavljene ključne karakteristike $i$ efekti primene lean $i$ six sigma koncepata $u$ proizvodnji i lancima snabdevanja. Pažnja će biti posvećena okvirima i potencijalima implementiranja lean koncepta u Republici Srbiji. Zatim će biti prikazane mogućnosti integrisanja pomenutih koncepata u lean six sigma koncept i razmotrena njegova uloga u otklanjanju nedostataka u poslovnim procesima. U pretposlednjem delu rada biće prikazana ključna obeležja lean lanca snabdevanja, dok će poslednji deo sadržati matematičke okvire dizajniranja six sigma lanca snabdevanja.

Ključne reči: lean proizvodnja, six sigma, lean lanac snabdevanja, poslovni proces, preciznost isporuke 